\title{
Delay in anal cancer diagnosis as a non-AIDS- defining malignancy
}

\author{
Justine Cohen ${ }^{1 *}$, John Stern², David Henry ${ }^{3}$ \\ From $12^{\text {th }}$ International Conference on Malignancies in AIDS and Other Acquired Immunodeficiencies \\ (ICMAOI) \\ Bethesda, MD, USA. 26-27 April, 2010
}

\section{Background}

Anal cancer is not considered an AIDS-defining malignancy (ADM). Nevertheless, the frequency of both anal intraepithelial neoplasia and invasive squamous cell carcinoma of the anus continues to increase in the HIV/AIDS population. As in cervical cancer, an ADM, numerous studies have established a causal relationship between highrisk types of human papillomavirus (HPV) infection and anal cancer [1]. In cervical cancer, the diagnosis is typically established at or near the time of HIV diagnosis [2]. The goal of this study was to evaluate and ascertain the interval from HIV diagnosis to anal cancer diagnosis.

\section{Materials and methods}

Medical records were retrospectively reviewed in $25 \mathrm{HIV}+$ patients with documented anal cancer. Cases were selectively analyzed using preexistent diagnosis dates of HIV infection. Surgical pathology reports were examined to corroborate the diagnosis of anal cancer.

\section{Results}

In all 25 patients, anal cancer was biopsy-proven between 1 and 25 years after a diagnosis of HIV infection, with a mean of 11.43 years (Table 1). Greater than $95 \%$ of patients were compliant on antiretroviral therapy at the time of cancer diagnosis. This study identified a considerable delay in anal cancer diagnosis in all cases (Figure 1).

\section{Conclusions}

The frequency of anal cancer within the HIV/AIDS population continues to increase despite effective

\footnotetext{
*Correspondence: justineco@gmail.com

'Department of Internal Medicine, Pennsylvania Hospital, University of

Pennsylvania Health System, Philadelphia, PA, USA

Full list of author information is available at the end of the article
}

Table 1

\begin{tabular}{|c|c|c|}
\hline $\begin{array}{l}\text { Years elapsed from HIV } \\
\text { diagnosis to anal cancer } \\
\text { diagnosis }\end{array}$ & $\begin{array}{l}\text { \# of patients/ } \\
\text { Years elapsed }\end{array}$ & $\begin{array}{l}\text { Cumulative } \\
\text { number of } \\
\text { patients }\end{array}$ \\
\hline 1 & 1 & 1 \\
\hline 2 & 1 & 2 \\
\hline 3 & 0 & 2 \\
\hline 4 & 1 & 3 \\
\hline 5 & 2 & 5 \\
\hline 6 & 0 & 5 \\
\hline 7 & 2 & 7 \\
\hline 8 & 2 & 9 \\
\hline 9 & 1 & 10 \\
\hline 10 & 1 & 11 \\
\hline 11 & 2 & 13 \\
\hline 12 & 0 & 13 \\
\hline 13 & 2 & 15 \\
\hline 14 & 2 & 17 \\
\hline 15 & 2 & 19 \\
\hline 16 & 2 & 21 \\
\hline 17 & 1 & 22 \\
\hline 18 & 0 & 22 \\
\hline 19 & 0 & 22 \\
\hline 20 & 0 & 22 \\
\hline 21 & 2 & 24 \\
\hline 22 & 0 & 24 \\
\hline 23 & 0 & 24 \\
\hline 24 & 1 & 25 \\
\hline 25 & 0 & 25 \\
\hline
\end{tabular}

antiretroviral therapy. This study reveals that unlike cervical cancer as an ADM, there is a frequent lag in identifying anal cancer among HIV patients. Given the known progression of HPV to cancer despite anti-retroviral therapy, it is imperative that health care providers include a closer examination of the perianal area on a 


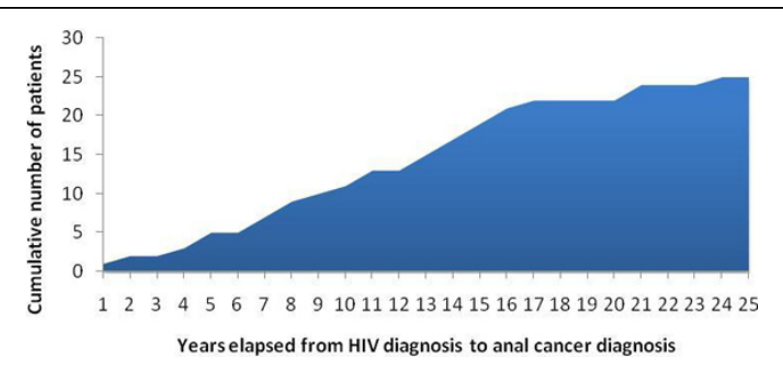

Figure 1 Delay in anal cancer diagnosis in years by cumulative number of patients

regular and continuing basis. We believe that increased awareness of anal cancer in the setting of HIV/AIDS will lead to earlier recognition, timely treatment, as well as improved outcome and long-term survival.

\section{Acknowledgements}

This article has been published as part of Infectious Agents and Cancer Volume 5 Supplement 1, 2010: Proceedings of the $12^{\text {th }}$ International Conference on Malignancies in AIDS and Other Acquired

Immunodeficiencies (ICMAOI). The full contents of the supplement are available online at http://www.biomedcentral.com/1750-9378/5?issue=S1.

\section{Author details}

'Department of Internal Medicine, Pennsylvania Hospital, University of Pennsylvania Health System, Philadelphia, PA, USA. ${ }^{2}$ Department of Infectious Diseases, Pennsylvania Hospital, University of Pennsylvania Health System, Philadelphia, PA, USA. ${ }^{3}$ Department of Hematology and Oncology,

Pennsylvania Hospital, University of Pennsylvania Health System, Philadelphia, PA, USA.

Published: 11 October 2010

doi:10.1186/1750-9378-5-S1-A16

Cite this article as: Cohen et al: Delay in anal cancer diagnosis as a non-AIDS-defining malignancy. Infectious Agents and Cancer 2010 5(Suppl 1):A16.

\section{Submit your next manuscript to BioMed Central} and take full advantage of:

- Convenient online submission

- Thorough peer review

- No space constraints or color figure charges

- Immediate publication on acceptance

- Inclusion in PubMed, CAS, Scopus and Google Scholar

- Research which is freely available for redistribution

Submit your manuscript at www.biomedcentral.com/submit 